\title{
Yield of Male Contact DNA Evidence in an Assault Simulation Model
}

\author{
Michael P Sandoval' ${ }^{1}$, Jillian NG ${ }^{2}$, William M Green ${ }^{3}$, Edward A Panacek ${ }^{4}$ and Sree Kanthaswamy ${ }^{1-5 *}$ \\ ${ }^{1}$ Forensic Science Graduate Program, University of California Davis, Davis, CA 95616, USA \\ ${ }^{2}$ Molecular Anthropology Laboratory, Department of Anthropology, University of California Davis, Davis, CA 95616, USA \\ ${ }^{3}$ California Clinical Forensic Medical Training Center, Sacramento, CA 95814, USA \\ ${ }^{4}$ Department of Emergency Medicine, University of California Davis Medical Center, Sacramento, CA 95817, USA \\ ${ }^{5}$ Department of Environmental Toxicology, University of California Davis, Davis, CA 95616, USA
}

\begin{abstract}
The conditions under which contact DNA analysis yields useful recovery of materials is not well known. Using simulated models of grabbing and struggling, the recovery of male contact DNA transferred from male "assailants" to female "victims" was investigated. The upper and lower arm areas of female subjects (sites for the modeled assaults) were swabbed for male DNA. Extracted DNA was quantified using the Quantifiler ${ }^{\circledR}$ Duo DNA Quantification kit and amplified using the AmpFISTR ${ }^{\circledR}$ Identifiler ${ }^{\circledR}$ and the AmpFISTR ${ }^{\circledR}$ Yfiler ${ }^{T M}$ PCR Amplification kits. The qPCR quantification results detected male "assailant" DNA from the female "victims". However, no viable male profiles were obtained when the DNA was subjected to short tandem repeat (STR) analysis with the Identifiler ${ }^{\circledR}$ and Yfiler $^{\text {TM }}$ kits.

The grab and struggle scenarios yielded up to $20 \mathrm{pg} / \mu \mathrm{L}$ and $40 \mathrm{pg} / \mu \mathrm{L}$ of male contact DNA from female subjects respectively, DNA amounts which are below the detection threshold of most commercial human STR identification kits. Although contact DNA levels are highly variable, this study showed that the likelihood of DNA deposition on skin from assailant to victim was substantially greater when a struggle ensues. The results of the present study are limited by small sample size, but imply that further research for improving recovery and amplification techniques of contact DNA should be sought to increase the probative value of this evidence in sexual assault investigations.
\end{abstract}

Keywords: Contact DNA; Sexual assault; Forensic science; Short tandem repeats (STRs); Quantitative real-time polymerase chain reaction (qPCR); DNA profiling; DNA quantification

\section{Introduction}

"Contact DNA", "touch DNA", and "trace DNA" pertain specifically to DNA associated with skin epithelial cells deposited on various surfaces $[1,2]$. Throughout this paper, the term contact DNA will be used to refer to this type of DNA sample. Contact DNA is typically recovered by swabbing surfaces without visible signs but suspected to have been touched or held by a purported assailant. Contact DNA can be collected from most substrates including clothing, steering wheels, door handles, weapons, as well as human skin [3-9]. Skin to skin transmission of contact DNA has been studied for over a decade $[10,11]$, but the true potential of contact DNA as probative evidence was not realized until the murder investigation of JonBenet Ramsey. The analysis of contact DNA resulted in the clearance of JonBenet's parents, the primary suspects, of any charges associated with their daughter's murder [12].

Compared to bloodstains or other bodily fluids, cellular material and associated DNA from contacts often involve no more than five to six epithelial cells [3,7], making it difficult to acquire a useful profile. Since low template DNA concentrations are expected for contact DNA, investigators searching for this evidence material must decide where and how often to collect samples. It would be logical to first establish the context of the crime. Therefore, forensic examiners are instructed to take very careful histories from victims, describing the sites of contact, nature of struggles, and degree of force involved, and follow specific collection procedures to maximize useful specimen collection. However, there is little evidence basis for specimen collection recommendations and best practices have yet to be determined. The results of contact DNA analysis could help investigators determine what events took place, might corroborate the victim's story, as well as support specific crime charges [8]. Predicting the success rate of obtaining a viable
DNA profile from a touched surface or held object is complicated [7] and depends on several major factors, including the shedder status of the individual, the hand used, the activities of the individual prior to contact, and the nature of the surface (i.e. porous vs. non-porous) [4]. The hand used is an important factor because, if a person is right hand dominant for example, he or she will tend to have a tighter grip with that hand, and in theory, will deposit more skin cells onto whatever he or she touches.

In the United States, an average of 207,754 sexual assaults (including unwanted touching, fondling, kissing, or other unsolicited contact between males and female victims) occur each year [13,14]. DNA analysis of epithelial cells from suspects in cases of sexual assault can be critical during investigation. Two contact DNA studies [10,11] have focused on sexual assault related contact DNA, but none have specifically looked at DNA recovery within the context of forcible interactions such as grabbing and struggling without additional contact such as sexual or oral intercourse, or other violent assailant-victim interactions such as strangling, choking, biting, and scratching. The ability to accurately detect and quantify male nuclear DNA in mixed samples is important in instances where target (male) DNA is overwhelmed by non-target (female) DNA.

*Corresponding author: Sree Kanthaswamy, Department of Anthropology, University of California Davis, One Shields Avenue Davis, CA 95616, USA, Tel: 530-752-1588; Fax: 530-752-8885; E-mail: skanthaswamy@ucdavis.edu

Received November 27, 2013; Accepted November 29, 2013; Published December 04, 2013

Citation: Sandoval MP, Jillian NG, Green WM, Panacek EA, Kanthaswamy S (2013) Yield of Male Contact DNA Evidence in an Assault Simulation Model. J Forensic Res T1: 002. doi:10.4172/2157-7145.T1-002

Copyright: (C) 2013 Sandoval MP, et al. This is an open-access article distributed under the terms of the Creative Commons Attribution License, which permits unrestricted use, distribution, and reproduction in any medium, provided the original author and source are credited. 
The objective of this study is to determine if amplifiable amounts of male assailant contact DNA can be recovered from the skin of female victims after simulated acts of grabbing and struggling. If the results of this study show that contact DNA from male assailants can be readily obtained, collection of this physical evidence should be considered for sexual assault investigations.

\section{Materials and Methods}

Four subjects, two male "assailants" and two female "victims", were recruited and paired into three male assailant-female victim couples to model common assault combinations. The third couple was comprised of the female from the first couple and the male from the second couple. Immediately prior to the study, male subjects were asked to wash their hands, while female subjects were asked to wash both their wrists and upper arms to minimize secondary transfer DNA from people outside the experiment. This precaution to avoid third party contamination was taken even though Daly et al. [9] reported that profiles generated from touched surfaces most likely derive from primary transfers. Other than the simulated assault acts, physical contact between the two subjects was avoided during and outside the period of the study. Approximately five minutes lapsed between the male and female subjects washing and when the assault simulations began. As a result, there may have not have been enough skin cells that sloughed off the male's hands initially in order to produce a DNA profile.

To simulate the grab situation, male participants were instructed to grab the left wrists of their paired female subject for five seconds using the male's right hand. The contact time of five seconds was chosen arbitrarily. The male subjects were also instructed to grab their female subjects' left upper arms using their right hand for five seconds as well. The grabbed wrist area was swabbed with low pressure within 30 minutes ( 0 hours) after the victim-assailant interaction using the double swab method to maximize DNA yield [7]. The double swab method consisted of first swabbing the area with a sterile cotton swab moistened with sterile water followed by a sterile, dry cotton swab [10,11]. This technique replicates the approach sexual assault forensic examiners most commonly use to collect samples. The experiment was repeated with the males grabbing the right wrists, and right upper arms of their female "victims" using the male's left hand. For this set of experiments, the female "victims" were instructed to not resist or struggle. Samples from each event were collected and stored separately at $-20^{\circ} \mathrm{C}$ prior to DNA extraction.

For the struggle situation, male participants were instructed to grab the female volunteers' right wrists for 10 seconds while the females struggled to release the male participants' grip. The contact time of 10 seconds was again chosen arbitrarily. No washing of either the female subjects wrists or the male subjects hands occurred after the grabbing simulations took place. The same simulated acts were repeated on the female's left wrists, and left and right upper arms and the same collection methods as the grab scenario were used. The entire experiment involving the different grab and struggle situations was replicated again on three separate days. Control double-distilled water $\left(\mathrm{ddH}_{2} \mathrm{O}\right)$ samples and buccal mouth swabs from each volunteer were collected as reference samples and stored at $-20^{\circ} \mathrm{C}$ prior to DNA extraction.

\section{Sample extraction}

Once all the swabs, both wet and dry, were collected, the tips of the cotton swabs were cut using sterile scissors and placed into $1.5 \mathrm{ml}$ centrifuge tubes. The contact DNA samples were extracted using the QIAamp DNA Investigator kit (Qiagen Inc., Valencia, CA) according to vendor protocols for swab extractions in a laboratory space dedicated to LCN DNA extractions. The reference buccal samples were extracted using the Qiagen Tissue Extraction kit (Qiagen Inc., Valencia, CA). The purified DNA extracts were stored at $-20^{\circ} \mathrm{C}$ until quantification of the samples.

\section{Sample quantification and fragment sizing}

The DNA extracts were quantified using the Quantifiler ${ }^{\circledR}$ Duo DNA Quantification Kit (Applied Biosystems, Carlsbad, CA) following the manufacturer's recommendations and run on an Applied Biosystems 7500 Real-Time PCR System. The kit simultaneously quantifies human DNA (from both male and female volunteers) as well as human male-specific DNA based on the amplification of the human RPPH1 (Ribonuclease P RNA Component H1) and the SRY (Sex determining region $\mathrm{Y}$ ) loci, respectively [13].

After quantification, samples were amplified with the AmpFISTR ${ }^{\circ}$ Identifiler $^{\circledR}$ and the AmpFlSTR ${ }^{\circledR}$ Yfiler $^{\mathrm{TM}}$ PCR Amplification Kits (Applied Biosystems, Carlsbad, CA) following manufacturer's protocols. The amplified products were electrophoresed using an Applied Biosystems 3130xl Genetic Analyzer and the data collected and analyzed with the Applied Biosystems Data Collection v3.0 and Genemapper ID v4.1 software (Applied Biosystems, Carlsbad, CA), respectively.

\section{Results}

Based on the DNA quantification, the reference buccal samples contained ample amounts of template DNA. The male reference samples yielded $58.4 \mathrm{ng} / \mu \mathrm{L}$ and $23.7 \mathrm{ng} / \mu \mathrm{L}$ of human DNA and 51.5 $\mathrm{ng} / \mu \mathrm{L}$ and $21.7 \mathrm{ng} / \mu \mathrm{L}$ of male specific DNA (based on the SRY target), respectively. The extracts from both females were quantified at $22.6 \mathrm{ng} /$ $\mu \mathrm{L}$ and $26.9 \mathrm{ng} / \mu \mathrm{L}$ of total DNA.

The Quantifiler ${ }^{\circledR}$ Duo kit detected the presence of male-specific DNA on both wrists and upper arms of the female subjects. The rates and the amounts are displayed in Table 1. Although both grab and struggle situations yielded variable amounts of male and total DNA, the

\begin{tabular}{|c|c|c|c|c|c|c|}
\hline \multirow[b]{2}{*}{ Type of situation } & \multicolumn{2}{|c|}{$\begin{array}{c}\text { Couple 1: Male } \\
\text { 1-Female1 }\end{array}$} & \multicolumn{2}{|c|}{$\begin{array}{l}\text { Couple 2: Male } \\
\text { 2-Female } 1\end{array}$} & \multicolumn{2}{|c|}{$\begin{array}{c}\text { Couple 3: Male } \\
\text { 2-Female } 2\end{array}$} \\
\hline & Human & Male & Human & Male & Human & Male \\
\hline \multirow[t]{2}{*}{ Left Wrist Grab } & 10 & $10^{*}$ & $20^{*}$ & $20^{*}$ & Und & Und \\
\hline & Und & Und & Und & Und & Und & Und \\
\hline \multirow{2}{*}{$\begin{array}{l}\text { Left Wrist } \\
\text { Struggle }\end{array}$} & 10 & 3 & $50^{*}$ & $20^{*}$ & 2 & 1 \\
\hline & Und & Und & Und & Und & 1 & 4 \\
\hline \multirow{2}{*}{$\begin{array}{l}\text { Left Upper Arm } \\
\text { Grab }\end{array}$} & 5 & 4 & Und & Und & Und & Und \\
\hline & Und & Und & Und & Und & 2 & $13^{*}$ \\
\hline \multirow{2}{*}{$\begin{array}{l}\text { Left Upper Arm } \\
\text { Struggle }\end{array}$} & 11 & $8^{*}$ & $40^{*}$ & $40^{*}$ & 2 & 2 \\
\hline & 5 & 2 & Und & Und & 1 & 1 \\
\hline \multirow[t]{2}{*}{ Right Wrist Grab } & 10 & $10^{*}$ & Und & Und & 5 & 3 \\
\hline & Und & Und & Und & Und & Und & Und \\
\hline \multirow{2}{*}{$\begin{array}{l}\text { Right Wrist } \\
\text { Struggle }\end{array}$} & 10 & $20^{*}$ & $60^{*}$ & $30^{*}$ & Und & Und \\
\hline & 1 & $13^{*}$ & Und & Und & Und & Und \\
\hline \multirow{2}{*}{$\begin{array}{l}\text { Right Upper Arm } \\
\text { Grab }\end{array}$} & Und & Und & Und & Und & Und & Und \\
\hline & Und & Und & Und & Und & Und & Und \\
\hline \multirow{2}{*}{$\begin{array}{l}\text { Right Upper Arm } \\
\text { Struggle }\end{array}$} & 1 & 6 & $20^{*}$ & $40^{*}$ & Und & Und \\
\hline & 1 & 3 & Und & Und & Und & Und \\
\hline
\end{tabular}

Table 1: Concentrations $(\mathrm{pg} / \mathrm{\mu L})$ of contact DNA derived from the two experimental situations conducted in duplicate for each couple (Und: undetected). Asterisks indicate measurements of DNA quantification that exceeded the minimum detection limit of the Quantifiler ${ }^{\circledR}$ Duo kit for total human DNA $(11.5 \mathrm{pg} / \mu \mathrm{L})$ and male DNA $(7.0 \mathrm{pg} / \mu \mathrm{L})$. 
struggle situations consistently detected more male DNA than the grab situations. A successful result in regards to the quantification data is one where the detected male DNA concentration is above the minimum quantifiable threshold of the Quantifiler ${ }^{\circledR}$ Duo kit for male DNA $(7.0 \mathrm{pg} / \mu \mathrm{L})$, as described in the Applied Biosystems 7500 Real Time PCR system user manual. The maximum concentration of total DNA extracted was $40 \mathrm{pg} / \mu \mathrm{L}$ in "grab" situations and $90 \mathrm{pg} / \mu \mathrm{L}$ in "struggle" situations, whereas estimates of male DNA from the female's skin were up to $20 \mathrm{pg} / \mu \mathrm{L}$ in the "grab" situations and $40 \mathrm{pg} / \mu \mathrm{L}$ in the "struggle" situations (Table 1). Even though the likelihood of getting male DNA from struggle situations at levels that exceeded the minimum detection limit of the Quantifiler ${ }^{\circledR}$ Duo (seven out of 24 sampling events) was greater than grab situations (four of 24 sampling events), this was not significant $(\mathrm{P}=0.493$, Fisher's exact test). These measurements are well above the minimum detection levels of the Quantifiler ${ }^{\mathbb{B}}$ Duo kit for total human and male DNA. Additional sampling for contact DNA was not performed at later time periods because only minute quantities of contact DNA were recovered at 0 hours after the simulated interaction.

Despite an approximate 4:1 copy ratio of RPPH1 (two per individual) to SRY (one per male) in the sample, the male contact DNA was quantified at comparable levels to the total DNA amounts. The amounts of male DNA relative to that of total DNA may be due to the preferential PCR amplification of smaller SRY (130 bp) compared to those of RPPH1 (140 bp), and because the two targets (as designed in the kit) do not give the same answer. There is likely a variance in the assay performance and one over estimates and one underestimates compared with one another.

When contact DNA from the female subjects were analyzed with the AmpFISTR ${ }^{\circledR}$ Identifiler $^{\circledR}$ and Yfiler ${ }^{\mathrm{TM}}$ PCR Amplification kits, very few peaks were present, resulting in no full profiles across the 13 CODIS or the 17 Y-STR loci.

\section{Discussion}

Typically LCN DNA refers to samples with 100 pg of DNA or less $[1,2]$. In this study, up to $40 \mathrm{pg} / \mu \mathrm{L}$ of male DNA was found on female subjects and up to $60 \mathrm{pg} / \mu \mathrm{L}$ of total DNA concentration from both males and females. The struggle situation recovered larger amounts of male DNA than the grab situation, which is consistent with Linacre et al.s [15] assumption that transmission of cellular material and associated DNA is correlated with the amount of time and pressure exerted. However, the difference in DNA transferred during grab and struggle situations were not statistically significant in this study. As others have demonstrated in studies involving the transmission of contact DNA, stochastic variation in terms of contact DNA transfer and recovery probably led to differences in quantification estimates between the different grab and struggle situations. Among their 30 volunteers, Lowe [16] found $51-70 \%$ of their subjects transferred little to no DNA onto the surface of a sterile tube that was held for 10 seconds. Rutty [11] showed that only 19 of 29 mock strangulation samples yielded viable DNA and only seven of them contained DNA from both victim and suspect. Conceivably more pressure was likely applied during simulated strangulation in their study compared to this one that relied on mock grabbing and struggling, and in spite of this, stochastic effects, including allelic dropout, were observed in both studies.

Our results showed that no full or usable profiles were attainable with the AmpFlSTR ${ }^{\circledR}$ Identifiler $^{\circledR}$ PCR Amplification kit. Even the Yfiler ${ }^{\mathrm{r}}$, which was designed to detect trace male DNA in a predominantly female background and has been shown to generate complete profiles with less than $60 \mathrm{pg}$ of DNA $[17,18]$, did not yield usable profiles.
Using the AmpFlSTR ${ }^{\circledR}$ MiniFiler ${ }^{\mathrm{TM}}$ PCR Amplification kit (Applied Biosystems, Carlsbad, CA), an adjunct to conventional STR kits due to its low template requirement, Grubwieser et al. [19] managed to reliably genotype samples containing at least $100 \mathrm{pg}$ of template DNA. Although not tested, the inclusion of the MiniFiler ${ }^{\mathrm{TM}}$ kit may have increased the likelihood of generating full profiles from the levels of contact DNA detected in the present study.

Furthermore, degraded DNA, which is recognized by a decrease or complete loss of genotype information selectively at the larger STR loci, was not observed in this study. All STR loci equally experienced a "decay curve" [20] as larger alleles were not disproportionately lost compared to the smaller ones.

Forensic biological samples are typically fraught with the effects of inhibition and degradation. As no environmentally challenged samples were used in this study, the suboptimal DNA profiles generated here do not reflect influences of inhibition and/or degradation. As such, this study has revealed limitations in commercial STR profiling kits for use in sexual assault cases involving contact DNA. Most samples submitted for forensic profiling contain DNA in amounts that are above the 0.1$0.5 \mathrm{ng}$ minimum required by the majority of common commercial STR kits. Below this range, standard methods tend to provide mainly partial profiles [7]. Since these kits were developed for use with higher DNA amount thresholds, they may not be sensitive enough to detect minute amounts of DNA from contact DNA samples recovered from human skin.

The similar rates of both male and total contact DNA detection imply that male epithelial cells deposited during an assault can be recovered from victims they grabbed or with whom they struggled. In spite of fluctuations in DNA yields between sampling within the same types of situation, the results demonstrate the applicability of using contact DNA in real casework. While both male and female contact DNA was successfully detected and quantified using $\mathrm{qPCR}$ technology, conventional end-point PCR with STRs failed to generate any informative profiles not only for the males but also for the females.

This difference between end-point and qPCR technologies in terms of low template amplification favors qPCR-based approaches to ultimately become the vehicle for optimal amplification of male contact DNA. Moreover, the real-time quantification feature of the qPCR technology also provides critical a priori information of the approximate DNA template quantity present for interpreting downstream genetic data [21-24]. Although partial STR profiles have been reported from samples that rendered negative qPCR results [25], observations based on the present study suggest that negative $\mathrm{qPCR}$ results should discourage further processing of contact DNA samples for fragment analysis, especially since the majority of commercial DNA typing kits used in forensic casework are optimized to yield accurate results down to a threshold of $0.1 \mathrm{ng}$ of template DNA [7].

Since so little contact DNA was recovered in spite of sampling almost immediately after simulated assaults involving grabbing and struggling, the current study did not investigate the aspects of shedder status [5] and temporal effects on the behavior of contact DNA [26]. The variability in the quantity of contact DNA recovered from the victims' skin in the present study may have been due to the shedder status of the "assailants" involved in the transfer process. Popa et al. [26] showed that epithelial cell constituents degrade with time and the degradation rates are dependent on the environmental conditions and substrate on which the cells were deposited. These findings underscore the importance of addressing both these major issues in future research 
Citation: Sandoval MP, Jillian NG, Green WM, Panacek EA, Kanthaswamy S (2013) Yield of Male Contact DNA Evidence in an Assault Simulation Model. J Forensic Res T1: 002. doi:10.4172/2157-7145.T1-002

Page 4 of 5

so that the recovery and detection of contact DNA may be enhanced in sexual assault casework.

While this study involves a small sample, the preliminary results imply that the analyses of male contact DNA from female sexual assault victims show promise especially in combination with qPCRbased approaches. Using TaqMan ${ }^{\circledR}$ qPCR chemistry, Kanthaswamy and Premasuthan [23], Kanthaswamy et al. [24], Barr et al. [27], and Ng et al. [28] have developed STR and SNP based assays that quantify nuclear DNA in a species-specific manner while addressing the problems of low template concentrations (as little as 2 to $4 \mathrm{pg} / \mu \mathrm{L}$ ), degraded, and low quality DNA. Using the same principle, qPCR amplification that uses $Y$ chromosome linked STR or SNP allele-specific fluorescent primers and hydrolysis probes may present a viable choice for profiling male contact DNA that is below the detection range of commercial STR typing kits.

Sexual assault cases can be difficult to investigate and prosecute. In some cases, demonstrating contact between the parties can be critically important. Contact DNA may provide this, but a reliable laboratory finding will require adequate collection by the forensic examiner, which is generally based on history to identify high yield contact sites. The results of this study could also generate recommendations directed to forensic examiners regarding specific historical details of the event in question that should be explored and documented. To be useful, samples must provide adequate DNA for a complete profile of the assailant. This first step only confirms contact and offers nothing regarding consent (which is also a critical determination in most sexual assault cases). The importance of proving contact alone is sufficient to continue the search for methodology to improve DNA recovery and analysis. Regarding the consent issue, this study found higher recovery rates of male DNA transfers with "struggle" than "grab" situations, even though none yielded enough for a profile. It is logical that more DNA will be transferred and recovered the more violent and prolonged the contact. It is conceivable that further investigation in this area might provide more specific correlation between the amount of DNA recovered and the nature (duration and severity) of the contact. The current study may have suffered from lower yields because the contact times (both grab and struggle) were shorter than what occurs in a real life assault situation. Again, the contact times were chosen arbitrarily and making them longer may have provided this pilot study with more data. Follow-up studies should address this variable.

\section{Ethical Standards}

We declare that this experiment complies with the current laws of the United States (US). The study was performed using universityapproved procedures (IRB Protocol Number 218115-3).

\section{Acknowledgements}

As partial satisfaction of the UC Davis Masters of Science (Forensic Science) program's requirement, Mr. Michael Sandoval's thesis, will be submitted to the UC Davis Office of Graduate Studies. This research was supported by a National Institute of Justice grant (2008-DN-BX-K288) awarded to Dr. Sree Kanthaswamy. We are most grateful to the UC Davis Molecular Anthropology Laboratory for their help and support. We also thank anonymous reviewers whose comments and suggestions have significantly improved this thesis.

\section{References}

1. Gill P, Whitaker J, Flaxman C, Brown N, Buckleton J (2000) An investigation of the rigor of interpretation rules for STRs derived from less than $100 \mathrm{pg}$ of DNA. Forensic Sci Int 112: 17-40.

2. Gill $P$ (2001) Amplification of low copy number DNA profiling. Croat Med J 42: 229-232.

3. Schulz MM, Reichert W (2000) A strategy for STR-analysis of cryptic epithelial cells on several textiles in practical casework. In Progress in forensic genetics, Sensabaugh GF, Lincoln PJ, Olaisen B, Eds.Elsevier: Amsterdam 8: 514-516.

4. Wickenheiser RA (2002) Trace DNA: a review, discussion of theory, and application of the transfer of trace quantities of DNA through skin contact. $J$ Forensic Sci 47: 442-450.

5. Phipps M, Petricevic S (2007) The tendency of individuals to transfer DNA to handled items. Forensic Sci Int 168: 162-168.

6. Bond JW, Hammond C (2008) The value of DNA material recovered from crime scenes. J Forensic Sci 53: 797-801.

7. Van Oorschot RAH, Jones MK (1997) DNA fingerprints from fingerprints Nature 387: 767

8. Williamson AL (2012) Touch DNA: Forensic collection and application to investigations. J Assoc Crime Scene Reconstr 18 :1-6.

9. Daly DJ, Murphy C, McDermott SD (2012) The transfer of touch DNA from hands to glass, fabric and wood. Forensic Sci Int Genet 6: 41-46.

10. Wiegand P, Kleiber M (1997) DNA typing of epithelial cells after strangulation. Int J Legal Med $110: 181-183$

11. Rutty GN (2002) An investigation into the transference and survivability of human DNA following simulated manual strangulation with consideration of the problem of third party contamination. Int J Legal Med 116:170-173.

12. Maloney JJ, O'Connor JP (1999) The Murder of JonBenet Ramsey. Crime magazine.

13. Barbisin M, Fang R, O'Shea CE, Calandro LM, Furtado MR, et al. (2009) Developmental Validation of the Quantifiler ${ }^{\circledR}$ Duo DNA Quantification Kit for Simultaneous Quantification of Total Human and Human Male DNA and Detection of PCR Inhibitors in Biological Samples. J Forensic Sci 54: 305-319.

14. Truman J (2011) Crime Victimization, 2010. Bureau of Justice Statistics.

15. Linacre A, Pekarek V, Swaran YC, Tobe SS (2010) Generation of DNA profiles from fabrics without DNA extraction. Forensic Sci Int Genet 4: 137-141.

16. Lowe A, Murray C, Whitaker J, Tully G, Gill P (2002) The propensity of individuals to deposit DNA and secondary transfer of low level DNA from individuals to inert surfaces. Forensic Sci Int 129: 25-34.

17. Mulero JJ, Chang CW, Calandro LM, Green RL, Li Y, et al. (2006) Development and validation of the AmpFISTRs YfilerTM PCR amplification kit: a male specific, single amplification 17 Y-STR multiplex system. J Forensic Sci 51 64-75.

18. Gross AM, Liberty AA, Ulland MM, Kuriger JK (2008) Internal Validation of the AmpFISTR Yfiler ${ }^{\mathrm{TM}}$ Amplification Kit for Use in Forensic Casework. J Forensic Sci 53: 125-134.

19. Grubwieser P, Mühlmann R, Berger B, Niederstätter H, Pavlic M, et al. (2006) A new "miniSTR-multiplex" displaying reduced amplicon lengths for the analysis of degraded DNA. Int J Legal Med 120: 115-120.

20. Chung DT, Drábek J, Opel KL, Butler JM, McCord BR (2004) A study on the effects of degradation and template concentration on the amplification efficiency of the STR Miniplex primer sets. J Forensic Sci 49: 733-740.

21. Evans JJ, Wictum EJ, Penedo MCT, Kanthaswamy S (2007) Real-Time polymerase chain reaction quantification of canine DNA. J Forensic Sci 52: 93-96.

22. Barbisin M, Fang R, Furtado MR, Shewale JG (2011) Quantifiler ${ }^{\circledR}$ Duo DNA Quantification Kit: A guiding tool for short tandem repeat genotyping of forensic samples. J Forensic Res 2: 118.

23. Kanthaswamy S, Premasuthan A (2012) Quadriplex real-time PCR (qPCR) assay for human-canine-feline species identification and nuclear DNA quantification. Forensic Sci Int Genet 6: e97-e98.

24. Kanthaswamy S, Premasuthan A, Ng J, Satkoski JT, Goyal V (2012) Quantitative real-time PCR (qPCR) assay for human-dog-cat species identification and nuclear DNA quantification. Forensic Sci Int Genet 6: 290-295.

25. Cupples CM, Champagne JR, Lewis KE, Cruz TD (2009) STR profiles from DNA samples with "undetected" or low quantifiler results. J Forensic Sci 54:103-107.

26. Popa G, Potorac R, Preda N (2010) Method for fingerprints age determination. Rom J Leg Med 18:149-154.

27. Barr A, Premasuthan A, Satkoski J, Smith DG, George D, et al. (2011) A rapid 
Citation: Sandoval MP, Jillian NG, Green WM, Panacek EA, Kanthaswamy S (2013) Yield of Male Contact DNA Evidence in an Assault Simulation Model. J Forensic Res T1: 002. doi:10.4172/2157-7145.T1-002

Page 5 of 5

quantitative real-time PCR (qPCR)-based DNA quantification assay coupled with species-determination capabilities for two hybridizing Macaca species. Folia Primatol 82: 71-80.
28. Ng J, Satkoski J, Premasuthan A, Kanthaswamy S (2012) A TaqMan ${ }^{\circledast}$ multiplex assay for hoofed livestock species identification and nuclear DNA quantification. International Food Research Journal 19: 1279-1285. 